ISSN 2580-6580

E-ISSN 2597-9817

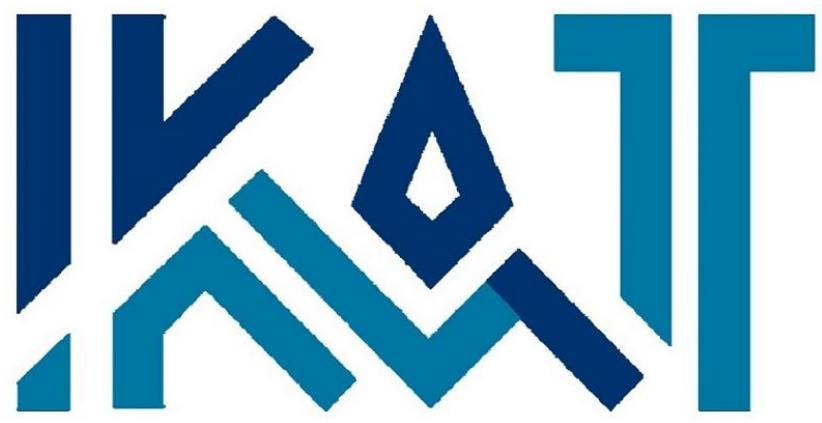

The Indonesian Journal of Southeast Asian Studies 


\section{IKAT \\ The Indonesian Journal of Southeast Asian Studies \\ Volume 2, Number 1, July 2018}

IKAT: The Indonesian Journal of Southeast Asian Studies is an academic journal about Southeast Asia. Founded in 2017 at the Center for Southeast Asian Social Studies Universitas Gadjah Mada, Yogyakarta, the journal aims to provide new, rigorous and comprehensive knowledge and understanding of the region. It has three special focuses: economic welfare, socio-cultural and political transformations, and developments in information and communication technology in Southeast Asia. We welcome critical and scholarly works in the humanities and social sciences to encourage more perspectives so that a broader horizon of important Southeast Asian issues can be discussed academically.

\section{Editorial Team}

\section{Editor-in-Chief}

Agus Suwignyo

Universitas Gadjah Mada, Indonesia

\section{Editorial Board}

Bambang Purwanto

Universitas Gadjah Mada, Indonesia

Tri Widodo

Universitas Gadjah Mada, Indonesia

Hermin Indah Wahyuni

Muhadi Sugiono

Al Makin

Universitas Gadjah Mada, Indonesia

Universitas Gadjah Mada, Indonesia

Sunan Kalijaga State Islamic University, Indonesia

\section{International Advisory Board}

Thomas B. Pepinsky

Cornell University, USA

Masaaki Okamoto

Kyoto University, Japan

David Robie

Jürgen Rüland

Judith Schlehe

Thomas Hanitzsch

Ariel Heryanto

Sunny Yoon

Sung Kyum Cho

Anthony Reid

Kosuke Mizuno

Auckland Technology of University, New Zealand

University of Freiburg, Germany

University of Freiburg, Germany

Ludwig-Maximilians-Universität München, Germany

Monash University, Australia

Hanyang University, South Korea

Chungnam National University, South Korea

Australian National University, Australia

Kyoto University, Japan

\section{Managing Editor}

Vissia Ita Yulianto

Theresia Octastefani

Andi Awaluddin Fitrah

Putu Yogi Paramitha

Universitas Gadjah Mada, Indonesia Universitas Gadjah Mada, Indonesia Universitas Gadjah Mada, Indonesia Universitas Gadjah Mada, Indonesia 


\section{IKAT The Indonesian Journal of Southeast Asian Studies}

Volume 2, Number 1, July 2018

\section{Contents}

Editorial Foreword

Jathilan Horse Dance: Spirit Possession Beliefs and Practices In The Present-Day Java

Eva Rapoport

History of Rakhine State and the Origin of Rohingya Muslims

Haradhan Kumar Mohajan

Postcolonial Hermeneutics: Concepts and Contribution to Understanding

Socio-Religious Problems in Indonesia

Novita Dewi

Online Perspectives on ASEAN-Japan Relations: Study of ASEAN-Related Japanese Tweets

Indah Santi Pratidina

'As If It Was Something Spoken By a Friend': Digital Vote-Canvassing Networks on Facebook During the 2013 Bangkok Gubernatorial Election Campaign

Mukda Pratheepwatanawong

Asia Pacific Report: A New Zealand Nonprofit Journalism Model for Campus-Based Social Justice Media

David Robie 


\title{
Online Perspectives on ASEAN-Japan Relations: An Analysis of ASEAN-related Japanese Tweets
}

\author{
Indah S. Pratidina 1
}

\begin{abstract}
ASEAN targets internal integration and strong external relations with its partner countries. Japan has stressed its long-standing support for ASEAN. The year 2013 saw the 40th anniversary of Japan-ASEAN relations when Japanese state actors put considerable efforts into marking this anniversary. Although Japan remains one of ASEAN's largest trading partners and sources of foreign direct investment, recent years has witnessed power relations dynamic in the region with China and South Korea actively engaging as well. State actors' statements and mainstream media coverage on ASEAN-Japan relations, particularly on economic and political security issues, had been the heavy focus of scholars interested in the field. An analysis of social media, and in particular Twitter, offers alternative insights for a more comprehensive observation.

The total of 3.29 million tweets containing the word "ASEAN" were collected from November 2013 to December 2015. From the dataset, it was identified that tweets using Japanese language are the third highest in volume after Indonesian and English. Content analyses were conducted to answer the questions on how ASEAN as an entity is viewed by the populations of its partner countries; which aspects of the integration project attract Twitter users' interests also, in the relation to strong external relations that ASEAN want to pursue, which countries are mentioned in the tweets and on which aspects? Using keywords from the Blueprints of ASEAN Community's integration aspects, the tweets were categorized as related to economics, political-security and socio-cultural topics. Countries mentioned in the dataset were counted and then categorized according to these aspects as well. The study finds economic and political-security themed tweets are the largest in volume with heavy mentioning of Japan, China and South Korea. Results suggest that online conversations about ASEAN are still strongly influenced by government and mainstream media's agenda.
\end{abstract}

Keywords: ASEAN, Japan, China, Twitter, Online Perspectives

\footnotetext{
${ }^{1}$ Graduated doctoral program from Institute of the Study of Global Issues, Graduate School of Social Sciences, Hitotsubashi University, Tokyo-Japan. Corresponding e-mail: ispdina@gmail.com
} 


\section{Introduction}

Since its establishment in 1967, the Association of Southeast Asian Nations (ASEAN) struggles to define its position internally and externally, between endeavors in engaging its citizens toward a people-centered community (Moorthy \& Benny, 2013; Nesadurai, 2011) and achieving firm-footing for its centrality in the eyes of region's partner countries (Katzenstein \& Shiraishi, 2006; Masashi, Chia, Soeya, \& Hassan, 2003; Yeo, 2006). The challenge has been re-acknowledged when it proclaimed a target of establishing ASEAN Community by 2015 comprises of an integrated economic, socio-cultural and political-security communities.

The project as unveiled in 2007 put equal emphasis on all three pillars, however, official statements and comments by political and business leaders as well as media coverage create the impression that ASEAN emphasizes economic rather than the other two aspects of integration. Letchumanan (2015) notes that cooperation and integration based on the economic pillar, i.e. AEC is the aspect of ASEAN integration that receives most attention in public discourse. Chalermpalanupap (2008, p. 25) writes that business people in the member states may be more or less aware of AFTA and ASEAN's external economic agreements, but ASEAN's profile and activities remain largely unknown to the wider general public living in the region.

ASEAN member states' increasing internal commitment in cooperation programs and plans of action since Bali Summit 1976, brought development of bilateral and multilateral relations with a widening range of cooperation fields with partner countries outside Southeast Asia (Chalermpalanupap, 2008). Japan has been one of the countries that stressed its long-standing support for ASEAN. The country remains one of ASEAN's largest trading partners and sources of foreign direct investment, claiming a strong cooperation ties in all three aspects of ASEAN integrations (Sukma \& Soeya, 2013). However, the recent years has witnessed power relations dynamic in the region with China actively engaging as well.

Studies on ASEAN, as well as ASEAN-Japan relations, have focused heavily on the state leaders, policy maker in international relations field (Hassan, 2003; Kawai, 2013; Rathus, 2011; Yeo, 2006). Arguing that there is also an importance to investigate actors who are engaged in the ASEAN discourse from all levels of society, grassroots level and government level, survey-based studies on public's attitude toward ASEAN 
community building were conducted in Southeast Asian countries (Moorthy \& Benny, 2012, 2013; Thompson \& Thianthai, 2008). This study proposes data from social media platform, Twitter, to gauge recent ASEAN-related themed discourses conducted in Japanese language. Social media has users from various level of society. Its accounts are owned by individual, communities, companies, private institutions, and government agencies; therefore, it proposes representation from a wide range of actors.

The ASEAN related Japanese tweets can give an external perspective on the questions on how ASEAN as an entity is viewed by the populations of its partner countries, particularly (1) which aspects of the integration project attract their interests?; and in the relation to external relations ASEAN want to pursue (2) which countries, and in which aspects, are mentioned in these online conversations?

Social media analysis does not offer a substitute for random-sample questionnaire surveys of the general population. Nevertheless, statista.com published that, as of January 2017, East Asia has the highest number of Internet users in the AsiaPacific region and Japan ranks third in the region with 101 million users (statista.com, 2017). Social media has been argued as an egalitarian platform that offers users from various social economic backgrounds to converse on the same level. Scholars have pointed its role in democratic development when used as platform for political aspirations in Asian countries (Abbott, 2012, 2013; Lim, 2003; Somantri, 2003). The study acknowledges the critique of digital divide but supports the notion that only few active gatekeepers may be needed to facilitate information exchanges (Abbott, 2011, 2013). Therefore, this study argues that analysis of online media offers an alternative way of assessing the idea of ASEAN among a significant minority of the population.

\section{Significance and Contributions}

The study contributes analysis of online media on ASEAN-Japan relations that is still scarce in the international relations studies. The findings in this study provide insights on how ASEAN is being discussed in terms of its integration aspects of economic, socio-cultural and political security by a partner country which will be useful for ASEAN related studies and projects in the future. This study sheds light on Japan's foreign relations being discoursed online, in particular how the Internet users 
view the position and relations of Japan and other partner countries in the East Asian region.

There is a need to take into consideration particular sets of political, social and cultural contexts when investigating social media practice (Bruns, 2015; Lim, 2013). In line with this, scholars argue that Asians may have adapted Internet utilization differently from those in the West (Ho, et al., 2003). Social media research, however, has predominantly focused on the practices of Western countries. This study offers a case on online media practices in Asia which is the home of a vast Internet user population.

\section{China in Japan-ASEAN Relations}

The year 1997 marked the first ASEAN+3 Summit at which Japan declared itself to be one of ASEAN's partner countries. Scholars argue that the necessity for economic cooperation between East Asian countries during the Asian financial crisis was the impetus for this (Shin, 2007; Soesastro, 2006; Terada, 2003). The crisis showed the need for an East Asian regional approach to financial problems and intensified the consciousness of mutual interdependence between Northeast and Southeast Asian countries (Terada 2003, p. 255).

ASEAN and Japan has shared long-standing economic relations which formally began in 1973 with the launch of the ASEAN-Japan forum on synthetic rubber. In recent years, China has also emerged as one of the big players in the region. Financial report from ASEAN Secretariat (2016) writes that in 2015, Japan is ASEAN's second largest source of foreign direct investment (FDI) after the EU with Japan originated inflows valued at US\$17.4 billion and accounted for 14.5 per cent of total FDI inflows to ASEAN. Two-way trade between ASEAN and Japan reached US $\$ 239.4$ billion, accounting for 10.5 per cent of ASEAN's in the same year, making Japan ASEAN's second largest trading partner after China (ASEAN Secretariat, 2016).

Economic cooperation was not the only reason for Japan to support ASEAN+3. Political gains were expected from the institution as a venue for policy dialogues with China and South Korea (Terada 2003, p. 268). Rathus (2011, p. 135) notes that "the rise of China was central in Japan's decision to promote multilateral security institutions" even before ASEAN+3. In the 1990s the Japanese government's quest for regionalism was at the forefront; however by 2000 China had become the driving force 
(Rozman, 2012). Japan's policies towards ASEAN have been shaped in the context of its evolving rivalry with China for influence and leadership in Southeast Asia (Hassan 2003). While China is approaching ASEAN to cooperate as a group rather than with particular member states one by one, Japan's approaches are more bilateral in nature (Miyagawa, 2007).

Japan has openly stated its support for ASEAN's community-building efforts and connects the initiative with broader East Asian regionalism (Kawai, 2013; Terada, 2012). In addition to economic, political, and security relations, Japan has acknowledged the necessity to consider social and cultural dimensions in this regional cooperation (Sukma \& Soeya, 2013; Yamamoto \& Hernandez, 2003). The idea that Japan's policy would go beyond economics and politics was initially stated in Prime Minister Fukuda Takeo’s “heart-to-heart” diplomacy in 1977. Almost every Japanese prime minister since Fukuda has proposed exchange program or created an institution to promote sociocultural related exchange with ASEAN countries (Yamamoto \& Hernandez, 2003). The 40th anniversary of Japan-ASEAN relations in 2013 and the 30th ASEAN-Japan Forum held in Phnom Penh in June 2015 show how state officials on both sides are reaffirming the importance of ASEAN-Japan Strategic Partnership.

\section{Media Perspectives on Japan's Foreign Relations}

The offline ASEAN-Japan relations and political atmosphere in Japanese online platforms provide rich background for analyses to ASEAN related conversations on Twitter. The long history of Japanese government engagement with ASEAN can be expected to influence the views of Japanese citizens towards ASEAN both offline and online. The mainstream media plays their role in firmly establishing this. State actors with high news value tend to promote economic and political security diplomacies, as well as integration with the Southeast Asian neighbors. Media outlets will be most likely to cover similar issues and this in turn will influence the content of social media.

Japan's foreign relations within the scope East Asian region are visible from issues highlighted by the mainstream media. Along with the heightened intra-trade, cultural exchange, and other activities, however, the media also pays attention to the politics of national identity practiced by the leaders of Japan, China and Korea (Shin, 2007). International Herald News of China, Asahi Shimbun of Japan, and Donga daily 
newspaper of South Korea each surveyed domestic perceptions of regional neighbors in 1990-2005. The survey done by the Asahi Shimbun showed that by 2005 , only about $15 \%$ of Japanese respondents held "favorable" views of Korea and only about $10 \%$ held "favorable" views of China (Shin, 2007). Results from surveys indicate strongly that nationalist politics appeal to these nations' younger generation in connection to issues of history (Shin, 2007, pp. 23-25).

Studies of Japan's online activities show the growing use of social media platforms to broadcast right-wing tendencies and nationalist sentiments (Kaigo, 2013; Miller, 2014). Japan's mainstream media operates under strict control mechanisms of Broadcasting Law which pressured them to avoid controversial issues and choose more politically neutral contents (Gatzen, 2001; Kirsch, 2016). A growing awareness of the limitations of state owned and mainstream commercial media led to acknowledgement of social media's social and political potential (Ichikawa \& Asakura, 2003; Kindstrand, et al., 2016).

The Matome Saito, curated websites that summarize entries on the Ni-Channel bulletin board (which is known for its users' right-wing tendencies), are considered by some Japanese to have higher credibility than the traditional media (Kaigo, 2013, p. 63). Kaigo explains that the Matome Saito are thus viewed because they are free from legal, social or other professional restraints (2013). He points out (2013, p. 64) that the Matome Saito provide an (in principle at least) open platform for ordinary citizens to express and discuss their honest political opinions on any issue. The comments give people who are browsing the Saito a sense that they are accessing ordinary citizens' views about each issue instead of reading another elite columnist's opinion in the newspaper or listening to an educated expert on television.

The right-wing Internet users, the Net-uyoku, exist in cyberspace only and differ from other conservatives and ultra-nationalistic groups in Japan (Kaigo, 2013). The group is characterized as: 1) anti-South Korean and anti-Chinese; 2) supporting politicians who honor the Yasukuni Shrine, support the revision of Article 9 of the Japanese Constitution, and enforce patriotism education in Japanese primary and middle schools through singing the national anthem and raising the national flag in schools, and; 3 ) active in online discussion and posting about political and social issues (Kaigo, 2013, p. 61). The group's seemingly loud voice online is due to frequent practices of commenting and re-tweeting between its members (Miller, 2014). China's 
geopolitical disputes with Japan over the East China Sea and with ASEAN over the South China Sea are among the issues that attracted their attention.

\section{Data and Methodology}

This study addresses the questions around the content of online communication particularly on Twitter in light of ASEAN Community (AC) building efforts in 2013 to 2015. When Twitter users discuss ASEAN, which aspects are they referring it toeconomic, political-security, or social-cultural? Also, related to the idea how Japan views ASEAN in its relations with other countries, which specific countries and/or region do they associate ASEAN with and their own positions in the relations?

Tweets containing the word "ASEAN" were collected from the Twitter API between November 2013 and December 2015 form the main data of this study. This period covered the two years leading up to the target date for the launch of the proposed ASEAN Community. Indonesian, English and Japanese are respectively the languages used most frequently within the collection period with total of 3.29 million tweets. This study focuses on 316,118 ASEAN-related tweets written in Japanese language. This dataset has been used before for a study case of political opinion leaders on Twitter which focuses on the actors who posted the Japanese ASEAN related tweets (Pratidina, 2018). The said article (Pratidina, 2018) and this study, both are parts from my dissertation which gauges ASEAN-related online conversations in Japanese, English and Indonesian on Twitter (Pratidina, 2017).

There are several reasons on choosing tweets as data. Although Twitter offers account owners privacy settings to protect access to their tweets, statuses posted on Twitter are public by default. This means that tweets can be read by anyone, regardless of whether they have a Twitter account or follow the author of the tweet. Twitter offers APIs for collecting tweets and other data, e.g. key users' profiles. From both technical and ethical points of view, this makes it easier to research compared with other social media platforms such as Facebook or Path which have stricter default privacy settings that limit readership (Kümpel, et al., 2015). Particularly for the case of Japan, Twitter ranks the third in Japan after LINE and Facebook and recorded 18.32 million unique visitors from the country as of May 2015 (statista.com, 2017). Twitter allows the Japanese writing system allows around three times as much 
information as English to be conveyed within the 140 character limit and therefore provides abundant materials to be analyzed.

This study uses counting algorithm scripts to see how many tweets were associated with categories from ASEAN integration aspects. Categorizations are in two main steps: (1) ASEAN integration aspects thematic analysis and (2) country mention and country categorization by ASEAN integration aspects thematic analysis.

For ASEAN integration aspects thematic analysis, the counting algorithm scored each tweet for words/phrases in the different categories. It then assigned the tweet to the category with the highest score. When two or three categories had equal scores for a tweet, the tweet was tagged as belonging to multiple categories. ASEAN Secretariat published three Blueprints as the standards for establishing an integrated ASEAN Community, both internally and externally. Blueprints of ASEAN Economic Community (AEC), ASEAN Socio-cultural Community (ASCC) and ASEAN PoliticalSecurity Community (APSC) (ASEAN, 2008, 2009a, 2009b). Dictionaries for tweets' content analysis mainly comprise core keywords excerpted from each Blueprint, e.g. keywords such as "industry" and "investment" into the AEC's dictionary, "army", "law enforcement" and "human rights" into the APSC dictionary, and "education", "poverty" and "disaster" into the ASCC's dictionary. All keywords were translated from English into Japanese.

In order to identify tweets related to one of the aspects but that did not contain any keywords from the Blueprints, the most frequently occurring words and trigrams-three-word sequences-in the tweets not assigned to any category were examined. These words and phrases were then added to one of the categories according to their meaning and context. The study took an inclusive approach, considering tweets mentioning companies to belong in the economic category and assigning those mentioning sports events and athletes' names to the socio-cultural category. The word count was re-run and the results were again checked; this was repeated several times in order to reduce the number of uncategorized tweets. The final version of the thematic dictionary contains 639 words. 
Table 1. Japanese Keywords Dictionary in Thematic Analysis

\begin{tabular}{|c|c|c|}
\hline Theme & $\begin{array}{c}\text { Number of } \\
\text { Words }\end{array}$ & Examples \\
\hline $\begin{array}{l}\text { Economic } \\
\text { terms }\end{array}$ & 257 & $\begin{array}{l}\text { アセアンフードフェア、インフラ、エアアジア } \\
\text { 、エコノミック、エネルギー、サービス、サイ } \\
\text { バーセキュリティ、スキル、ビジネス、ブラン } \\
\text { ド、ホールディングス、マーケティング、メー } \\
\text { カー、モノづくり、価格、会社、海外事業、外 } \\
\text { 貨、観光、企業、漁業、競争、金融、銀行、空 } \\
\text { 港、経営、経済、現地社員、交通、工場、航空 } \\
\text { 、購入、国産、産業、仕事、市場、資金、自動 } \\
\text { 車、借金、取引、所有権、商、消費者、情報シ } \\
\text { ステム、食材、食品、人材、世界銀行、生産、 } \\
\text { 製造、製品、税関、石炭、石油、造船、地下鉄 } \\
\text { 、中古車、中流階級、著作権、通貨、通販、鉄 } \\
\text { 道、天然ガス、電力、途上国、投資、東電、道 } \\
\text { 路、特許、日韓 } \mathrm{E} \mathrm{P} \text { A 、日韓 } \mathrm{F} \mathrm{T} \text { 、日建、入 } \\
\text { 国ビザ、農、発電、販売、品質、不動産、物価 } \\
\text { 、物資、物流、保険、貿易、民間、輸出、輸送 } \\
\text { 、輸入、融資、利益、旅行、料理、林業、労働 } \\
\text { ホテル }\end{array}$ \\
\hline $\begin{array}{l}\text { Political- } \\
\text { security terms }\end{array}$ & 162 & $\begin{array}{l}\text { IS対抗組織, mofajapan, NATO, イスラム国, サイバ } \\
\text { 一捜査, セキュリティ,デモ行進, デモ隊, テロ, テ } \\
\text { ロリスト,テロ対策, ファシスト, ロヒンギャ, 愛国 } \\
\text {,安全保障, 安保,慰安婦, 移民, 違法物件, 海軍, 海上 } \\
\text { の安全, 海上保安, 海兵隊, 海洋覇権, 海洋問題, 外 }\end{array}$ \\
\hline
\end{tabular}




\begin{tabular}{|c|c|c|}
\hline & & $\begin{array}{l}\text { 交, 外務省, 核ミサイル, 核兵器, 核保有, 核問題, 寛 } \\
\text { 容,危機, 規範, 偽造, 議員, 漁民, 共通の価值観, 共同 } \\
\text { 訓練 }\end{array}$ \\
\hline $\begin{array}{l}\text { Socio-cultural } \\
\text { terms }\end{array}$ & 220 & $\begin{array}{l}\mathrm{H} 5 \mathrm{~N} 6 \text { 型鳥インフル, HKT48, Jenesys, JKT48, Jリ } \\
\text { 一グ, アニメ, インフルエンザ, エボラ, オリンピッ } \\
\text { ク, お祭り, サッカー, ジェンダー, スポーツ, ダン } \\
\text { ス,ドラえもん, ドラマ,ファッションイベント, フ } \\
\text { エスティバル, フォーチュンクッキー, フットボ } \\
\text { ール, マンガ, 移住者, 遺産, 医用機器, 映画, 英語, 音 } \\
\text { 楽, 歌舞伎, 格差解消, 学校, 学生, 環球, 環境, 韓流, } \\
\text { 教育, 教育者, 教科書, 教師, 金メダリスト, 芸術, 健 } \\
\text { 康, 研究者, 言語学, 交流, 抗ウイルス薬, 高齢者, 国 } \\
\text { 際交流基金, 差別, 災害, 子供, 市民, 社会, 宗教, 女性 } \\
\text {, 女優, 奨学金, 少年, 障害, 食中毒, 食糧安全保障, 震 } \\
\text { 災, 震災復興, 人間開発, 人材育成, 生活, 青年, 選手, } \\
\text { 台風, 大学, 地球温暖化, 地震, 著者, 鳥インフレ, 伝 } \\
\text { 統, 東南アジア大会, 日本語, 俳優, 被災地, 美術館, } \\
\text { 病気, 貧困, 舞踊, 福祉, 文化, 防災, 漫画, 民族衣装, } \\
\text { 民族性, 留学 }\end{array}$ \\
\hline
\end{tabular}

(Source: Author's Compilation)

The dictionary method has a number of limitations, all of which were encountered in this project. First, it is unrealistic to build a keyword dictionary with full coverage. For one thing, words or phrases used in tweets will vary due to typing errors or individual preferences. Second, a reading of categorized Japanese tweets at the analysis stage showed that individual keywords and phrases do not always capture meaning. Many Japanese tweets mentioning countries such as China and South Korea were categorized as socio-cultural because they contained words in the 
socio-cultural keyword list. Closer investigation of tweets mentioning the two countries, however, revealed that they had a strong political nuance.

The country mention analysis was done in a similar process with the thematic analysis. Country names mentioned were counted from the tweets; a tweet may contain several country names therefore the count does not correspond to the actual number of tweets. The results were then scanned with ASEAN integration aspects thematic analysis' counting algorithm to show which aspects of integration are associated with particular countries. Dictionary was built containing the names of the ten ASEAN member states (Brunei, Cambodia, Indonesia, Laos, Malaysia, Myanmar, Philippines, Singapore, Thailand, Vietnam) plus 17 other regional and global powers (Japan, China, the US, South Korea, the EU, India, North Korea, Australia, Taiwan, Russia, UK, Germany, Turkey, Brazil, France, Canada, East Timor) in Japanese. Kanji character versions of country names were added to the dictionary, e.g. “中韓” for China and Korea and “日米” for Japan and the U.S. However, the variety of forms and the occasional ambiguity (e.g. “中国” as the country and the Japanese region) means some errors are inevitable.

\section{Results and Analysis}

Table 2 below shows the result of thematic analysis. The economic and politicalsecurity categories were very close in size, and much larger than the socio-cultural category.

Table 2. Japanese Tweets Categorized by Aspect of ASEAN Integration

\begin{tabular}{l|l|l}
\hline Aspect of ASEAN Integration & Tweets & Percentage \\
\hline Economy & 99,183 & $32 \%$ \\
\hline Political-security & 95,708 & $30 \%$ \\
\hline Socio-cultural & 60,098 & $19 \%$ \\
\hline Uncategorized & 61,192 & $19 \%$ \\
\hline TOTAL & $\mathbf{3 1 6 , 1 8 1}$ & \\
\hline
\end{tabular}

(Source: Author's Compilation) 
The busiest period for ASEAN-related Japanese tweets was mid-December 2013 when the 40th ASEAN-Japan Commemorative Summit was held in Tokyo (Pratidina, 2018). The tweets are mostly comments and retweets about the Summit and on Prime Minister Abe's conduct during the event. Observation from the tweets sent during this period of time reveals that statuses from accounts belonging to government institutions and politicians are hardly visible and in contrast, majority of tweets were posted by opinionated authors from non-authority groups, i.e. Personal Account and Intellectual categorized users (Pratidina, 2018).

Regardless of the time the tweets were posted, from the economic tweets, it was observable that authors of Japanese tweet were interested in economic ties between Japan and ASEAN in the context of Japan's rivalry with China, as well as in the ASEAN+3 framework. While economic cooperation with ASEAN was generally written about positively, tweets regarding China and South Korea as potential business partners were generally negative. Another topic was ASEAN relations with the EU and comparisons between the two regional associations.

Political-security tweets emphasized security cooperation between Japan and ASEAN. The main issues were the South China Sea dispute, and Japanese perceptions of their own country's security and position on the regional political chessboard. Some tweets explicitly positioned China as the common enemy of Japan and other Asian countries. They also expressed disappointment that the ASEAN countries did not stand up to China when addressing the South China Sea dispute despite appeals from Vietnam at ASEAN Summit in Myanmar (Pratidina, 2018).

Tweets in socio-cultural category heavily centered on the AKB48 and EXILE performance at the 40th ASEAN-Japan Commemorative Summit in December 2013. Posts containing critiques on Abe's choice of AKB48 and EXILE to perform at the Summit Gala Dinner were heavily retweeted (Pratidina, 2018). Other topics were ASEAN-related cultural events, as well as Japan's activities on Japanese language education in Southeast Asia which some viewed as Japan's soft power at work.

Many of the uncategorized Japanese tweets had a strong political nuance despite not containing political-security keywords. They frequently mentioned China and South Korea in the context of Japan's foreign relations. The fact that Japan did not invite China and South Korea to the Japan-ASEAN Summit in 2013, for example, attracted considerable attention. Many of these tweets positioned ASEAN as a group 
or its member states individually as Japan's allies against China and South Korea. Some expressed support for Prime Minister Abe's decision not to invite China and South Korea to the Japan-ASEAN Meeting in Tokyo, and gratitude for Indonesia support for Japan in a debate with South Korea at a Summit meeting. There were also tweets about the establishment of the ASEAN Community, and some tweets went further to enthuse about building an East Asian Community.

The overall look on the busy traffic dates of ASEAN related tweets reveals that Japanese tweets authors tend to send their tweets during large-scale ASEAN-Japan summits. Further observation that was available after categorization based on aspects of ASEAN integration suggests that regardless the category, ASEAN related Japanese tweets were dense with political nuance.

China and South Korea were mainly written in competitive tone, particularly when the countries' relations with Southeast Asian countries were discussed. Further analyses of country mention will present more weight to the argument.

In country mention analysis, for ASEAN countries, Myanmar, Vietnam and Thailand, got considerably amount of attentions. The Japanese tweets conversations though, were more strongly connected with the non-ASEAN countries of Japan, China, the U.S. and South Korea, particularly in conversations regarding power relations between them. Table 3 shows the numbers of references to the ten ASEAN states plus other regional and global powers in the Japanese tweets.

Table 3. Countries Mentioned in Japanese Tweets

\begin{tabular}{l|l|l|l}
\hline Country & Mentions & Country & Mentions \\
\hline \multicolumn{1}{l|}{ ASEAN } & 18,427 & Non-ASEAN & \multicolumn{2}{l}{} \\
\hline Vietnam & 16,537 & Japan & 108,608 \\
\hline Myanmar & 14,539 & China & 93,540 \\
\hline Thailand & 14,109 & USA & 35,406 \\
\hline Singapore & 13,199 & South Korea & 32,384 \\
\hline Indonesia & 11,578 & EU & 11,919 \\
\hline Cambodia & & India & 11,736 \\
\hline
\end{tabular}




\begin{tabular}{l|l|l|l}
\hline Malaysia & 10,560 & North Korea & 9,927 \\
\hline Laos & 10,426 & Australia & 9,163 \\
\hline Philippines & 9,552 & Taiwan & 8,598 \\
\hline Brunei & 2,109 & Russia & 4,883 \\
\hline & & UK & 4,197 \\
\hline & & Germany & 1,214 \\
\hline & & Turkey & 1,124 \\
\hline & & Brazil & 1,054 \\
\hline & & France & 792 \\
\hline & & Canada & 352 \\
\hline & & East Timor & 157 \\
\hline No country & 89,110 & & \\
\hline & & &
\end{tabular}

(Source: Author's Compilation)

Japan was mentioned most frequently followed by China, the U.S. and South Korea. South Korea, with the lowest count of the four, is mentioned almost twice more frequently than any of the ASEAN member states; the most frequently mentioned ASEAN states are Vietnam and Myanmar. The tweets mention China and South Korea in a negative context, but regard ASEAN more positively. This finding suggests a view among Japan's social media users of ASEAN as a dimension of Japan's relations with China, the U.S. and to a lesser extent South Korea, prompted by Prime Minister Abe's active engagement with ASEAN. Reading sample tweets, some users positioned Japan in the same grouping as ASEAN but positioned China and South Korea as rivals and excluded them from the regional entity (Pratidina, 2018).

Table 4. Japanese Tweets Countries Mentioned in Categories 


\begin{tabular}{|c|c|c|c|c|}
\hline & Economy & Socio-cultural & $\begin{array}{l}\text { Political- } \\
\text { security }\end{array}$ & No category \\
\hline \multicolumn{5}{|l|}{ ASEAN } \\
\hline Brunei & 462 & 588 & 545 & 514 \\
\hline Cambodia & 1,239 & 866 & 1,065 & 8,408 \\
\hline Indonesia & 1,563 & 2,449 & 4,424 & 4,763 \\
\hline Laos & 716 & 802 & 788 & 8,120 \\
\hline Malaysia & 1,162 & 2,806 & 2,428 & 4,164 \\
\hline Myanmar & 1,135 & 2,259 & 2,638 & 10,505 \\
\hline Philippines & 860 & 3,565 & 2,465 & 2,662 \\
\hline Singapore & 994 & 1,056 & 3,310 & 8,749 \\
\hline Thailand & 2,147 & 1,626 & 3,632 & 7,134 \\
\hline Vietnam & 1,504 & 3,986 & 1,962 & 10,975 \\
\hline \multicolumn{5}{|c|}{ NON-ASEAN } \\
\hline Australia & 193 & 5,834 & 796 & 2,340 \\
\hline Brazil & 51 & 89 & 109 & 805 \\
\hline Canada & 23 & 218 & 41 & 70 \\
\hline China & 3,426 & 51,486 & 14,531 & 24,097 \\
\hline East Timor & 29 & 4 & 109 & 15 \\
\hline EU & 439 & 3,552 & 1,441 & 6,487 \\
\hline France & 22 & 378 & 116 & 276 \\
\hline Germany & 73 & 357 & 545 & 239 \\
\hline India & 577 & 3,646 & 2,563 & 4,950 \\
\hline
\end{tabular}




\begin{tabular}{l|l|l|l|l}
\hline Japan & $\mathbf{1 6 , 1 6 2}$ & 41,541 & $\mathbf{1 6 , 3 5 5}$ & 34,550 \\
\hline North Korea & 4,197 & 1,466 & 512 & 3,752 \\
\hline Russia & 67 & 2,864 & 1,246 & 706 \\
\hline South Korea & 2,276 & 14,913 & 6,365 & 8,830 \\
\hline Taiwan & 459 & 3,999 & 981 & 3,159 \\
\hline Turkey & 42 & 143 & 460 & 479 \\
\hline UK & 2,228 & 947 & 582 & 440 \\
\hline USA & 1,183 & 26,320 & 3,071 & 4,832 \\
\hline
\end{tabular}

(Source: Author's Compilation)

Table 4 shows which aspects of integration are stressed in tweets mentioning particular countries. Tweets mentioning Japan tend to stress the socio-cultural aspects more, although political-security and economic tweets are also frequent. Tweets mentioning China heavily emphasize socio-cultural issues, followed by political-security and economic categories related topics. Tweets referring to South Korea and the U.S. also have a strong tendency towards socio-cultural content.

This finding suggests that ASEAN-related tweets in Japanese tended to mention major non-ASEAN powers in a socio-cultural context, even though in the overall counts, economy and political-security tweets were more numerous.

It is important to note that many of the socio-cultural tweets had strong political nuances, in many cases a less favorable sentiment toward China and South Korea. One example was the sharing of news stories showing or alleging behavior in China that is considered to be a violation of human or animal rights. Another common topic was the Japanese language; language is considered as one tool of soft power and therefore loosing Japanese language students to Chinese language enthusiasts in Southeast Asia was regarded by some users as losing pro-Japan supporters to China. The increased teaching of Chinese in Southeast Asian schools was viewed as an indication of China's rising economic and political importance, as well as of its growing soft power in the region (Feng, 2007). 
Another example of discourse was soft power competition were tweets about the K-Pop boom and the appointment of a top Korean actress as South Korean cultural ambassador. Other tweets addressed the environment and natural disaster, criticizing China's landfill activities that might destroy the coral reef habitat in South China Sea.

For the ten member states, Table 4 shows that political-security tweets are slightly larger on average compared to socio-cultural ones, while economic tweets are the least numerous. Indonesia and Thailand were the ASEAN countries most frequently mentioned in political-security tweets. Observation from the tweets shows that the interest was on Thailand's domestic political situation. In the context of the South China Sea dispute, some tweets mentioned disappointment in Thailand's siding with China over Japan and expressing appreciation for Indonesia's pro-Japan political stance (Pratidina, 2018). Tweets contained nostalgic references to Japan's role in Indonesia's gaining independence indicate example of nationalist sentiment find on online platform. It seems that the original posts are few in numbers but amplified due to the heavy retweets and comments.

Table 3 of country mention analysis shows Myanmar and Vietnam got considerably amount of attentions in the Japanese tweets. A more detailed analysis on aspects of integration categorization showed in Table 4 indicates Vietnam having considerably high count on socio-cultural category compared to other ASEAN countries. The topics on sporting events and cultural festival make up most of the tweets in this category. In contrast, the low counts for Myanmar indicate no particular inclination toward any integration aspects. Both countries, however, scored the highest on "No Category" with more than 10,000 counts if compared to their ASEAN counterparts. Numerous tweets that mentioned "Vietnam" in this category are related to the commemoration of 40th anniversary of Vietnam-Japan diplomatic ties which coincided with string of events at Tokyo in December 2013, including the $40^{\text {th }}$ ASEANJapan Commemorative Summit. Uncategorized tweets that mentioned "Myanmar" create concern of a possible bias made by the fact that the country hosted ASEAN Summits and other high level meetings in 2014 . The country might be mentioned as event venue and not on particular topic of interest.

It is worth stating that in general, Japanese tweets mentioning ASEAN countries were significantly fewer than those mentioning non-ASEAN countries. One reason for 
this could be that Japanese Twitter users tend to refer ASEAN as a united group instead of mentioning individual member states.

\section{Conclusion and Discussion}

This study sets out to establish the level and content of interest in the ASEAN integration project among the social media users of Japan, one of ASEAN's key partner countries, through content analyses. Findings offer alternative way to view ASEANJapan relations which have been heavily studied from the perspectives of government level interactions.

After thematic and country mention analyses, the data shows affirmations to the offline and online backgrounds presented in the earlier part of this paper. Discussion on Japan's relations with ASEAN in previous studies often operates in the context of East Asian regionalism, with particular focus of Japan's rivalry with China in securing economic and political influence in the region. Economic and political tweets composed the major counts from total Japanese tweets and even the socio-cultural and uncategorized tweets have dense political tendencies. The busy traffics seem to happen during ASEAN Summits and meetings which suggest that parallel to the coverage from mainstream media, ASEAN related conversations on Twitter also focus on summits and country leaders' conducts during these high profile events. It is important to note, however, that unlike politically neutral contents issued by the mainstream media, the tweets offer views that are not necessarily in approval with the ruling government, e.g. comments on Abe's choice of entertainment for high profile dinner at Japan-ASEAN Summit. This affirms the notion that Twitter in Japan is used as alternative platform for political expression by Internet users who are most likely belong to non-authority groups to counter the establishment.

Another point presented by the data is that ASEAN countries are generally mentioned less than non-ASEAN countries, which suggests a dominant presence of external powers in ASEAN online discourse. China in particular was a ubiquitous presence across categories. Although the U.S. and Japan were also frequently mentioned, on Twitter at least they seem to be receding in the face of China's vigorous efforts to plant its influence in the region. While facing harsh criticism on its conduct in the South China Sea-an issue that dominated political-security tweets-China was 
also mentioned more in socio-cultural tweets, demonstrating the widespread appeal of the country's cultural diplomacy.

In terms of ASEAN centrality from partner countries' points of view, previous research argues that China is approaching ASEAN to cooperate as a group while Japan's approaches are more bilateral in nature. This argument seems applicable only on government level. Findings from Japanese tweets show that Japanese Twitter users refer to the Southeast Asian countries not as individual countries but as a regional entity of ASEAN when addressing Japan foreign cooperation in the region. This view found in Japanese tweets, along with tweets celebrating the declaration of one ASEAN community at the end of 2015, might suggest external acknowledgement of the integrated ASEAN.

The analysis of the countries mentioned in the Japanese tweets suggests that concerns about national agendas coexist with regional interests. Many authors of Japanese tweets voiced their concerns in the possibility of losing the country's economic and political influences in Southeast Asian countries and therefore support active engagement in the region. Data shows some tweets with nationalist sentiment. While the majority of these conversations are themed with rivalries between Japan, China and South Korea, there were also tweets mentioning historical glory of Japan which claimed that the country helped Southeast Asian nations into independence. Therefore, it is valid to state that ASEAN related tweets are among the noticeable examples of online messages with strong Japan's nationalist sentiment. Further investigations are required, however, to determine whether the authors of these tweets consider themselves as members of the Internet right-wing group or not.

This study is the first to gauge online conversations on ASEAN-related issues. However, there is a need to acknowledge limitations. Conducting content analyses to online data had their challenges. Having abundant data means layers of tasks in order to minimize noise and produce clean data. Japanese language has its own particularities which demanded adjustments to analysis tools and although several iterations of word/phrase checking were carried out in order to improve the keyword dictionary for categorization, full coverage was impossible and a large proportion of tweets remained uncategorized.

\section{References}


Abbott, J. (2013). Introduction: Assessing the Social and Political Impact of the Internet and New Social Media in Asia. Journal of Contemporary Asia, 43(4), 579590.

(2012). Democracy@ internet. org Revisited: Analysing the Socio-Political Impact of the Internet and New Social Media in East Asia. Third World Quarterly, 33(2), 333-357.

. (2011). Cacophony or Empowerment?: Analyzing the Impact of New information Communication Technologies and New Social Media in Southeast Asia.

ASEAN. (2009a). ASEAN Political-Security Blueprint. Jakarta: The ASEAN Secretariat. . (2009b). ASEAN Socio-Cultural Community Blueprint. Jakarta: The ASEAN Secretariat. . (2008). ASEAN Economic Community Blueprint. Jakarta: The ASEAN Secretariat.

ASEAN Secretariat. (2016). Overview of ASEAN-Japan Dialogue Relations| ONE VISION ONE IDENTITY ONE COMMUNITY. Retrieved February 23, 2017, from http://asean.org/?static_post=overview-asean-japan-dialogue-relations

Bruns, A. (2015). Making Sense of Society through Social Media. Social Media + Society, 1(1), 2056305115578679.

Chalermpalanupap, T. (2008). Institutional Reform: One Charter, Three Communities, Many Challenges. Hard Choices: Security, Democracy, and Regionalism in Southeast Asia, 91-131.

Feng, Z. (2007). China's Regional Activism in East Asia. In G.-W. Shin \& D. C. Sneider (Eds.), Cross Currents: Regionalism and Nationalism in Northeast Asia (pp. 119139). Stanford, CA: The Walter H. Shorenstein Asia Pacific Research Center.

Gatzen, B. (2001). Media and Communication in Japan: Current Issues and Future Research. Electronic Journal of Contemporary Japanese Studies (Ejcjs), (Discussion Paper 2 in 2001). Retrieved from http://www.japanesestudies.org.uk/ discussionpapers/Gatzen.html

Hassan, M. J. bin. (2003). ASEAN's Political and Security Relations with Japan. In ASEAN-Japan Cooperation: A Foundation of East Asian Community (pp. 145-153). Japan Center for International Exchange. 
Ho, K. C., Kluver, R., \& Yang, C. C. (2003). Asia.com: Asia Encounters the Internet. Routledge.

Ichikawa, A., \& Asakura, A. (2003). The Internet and Media Democracy in Japan. In I. Banerjee (Ed.), Rhetoric and Reality: the Internet Challenge for Democracy in Asia (pp. 122-140). Singapore: Eastern Universities Press.

Kaigo, M. (2013). Internet Aggregators Constructing the Political Right Wing in Japan. JeDEM-eJournal of eDemocracy and Open Government, 5(1), 59-79.

Katzenstein, P. J., \& Shiraishi, T. (2006). Beyond Japan: The Dynamics of East Asian Tegionalism. Cambridge Univ Press.

Kawai, M. (2013, December 13). New Challenges for ASEAN-Japan relations: Celebrating the 40th year of ASEAN-Japan friendship and cooperation. Retrieved from http://www.asiapathways-adbi.org/2013/12/new-challengesfor-asean-japan-relations-celebrating-the-40th-year-of-asean-japanfriendship-and-cooperation/.

Kindstrand, L., Nishimura, K., Slater, D. H., Hjorth, L., \& Khoo, O. (2016). Mobilizing Discontent: Social Media and Networked Activism Since the Great East Japan Earthquake. In Routledge Handbook of New Media in Asia. New York: Routledge. Kirsch, G. (2016). Controlling the Media in Japan. Retrieved April 6, 2017, from http://nottspolitics.org/2016/07/11/controlling-the-media-in-japan/

Kümpel, A. S., Karnowski, V., \& Keyling, T. (2015). News Sharing in Social Media: A Review of Current Research on News Sharing Users, Content, and Networks. Social Media+ Society, 1(2), 2056305115610141.

Letchumanan, R. (2015). What is the ASEAN Community 2015? RSIS Commentary, (28), 3.

Lim, M. (2013). Many Clicks but Little Sticks: Social Media Activism in Indonesia. Journal of Contemporary Asia, 43(4), 636-657.

. (2003). The Internet, Social Networks, and Reform in Indonesia. In

Contesting media power: Alternative media in a networked world (pp. 273-288). Lanham, MD: Rowan \& Littlefield.

Masashi, N., Chia, S. Y., Soeya, Y., \& Hassan, M. J. bin. (2003). ASEAN-Japan Cooperation: A Foundation for East Asian Community. Japan Center for International Exchange. Miller, J. B. (2014). Loud for Their Size: Japan's Right Wing and Social Media. Global Asia, 9(No. 2), 40-41. 
Miyagawa, M. (2007). Regionalism: The View from Northeast Asia. In G.-W. Shin \& D. C. Sneider (Eds.), Cross Currents: Regionalism and Nationalism in Northeast Asia (pp. 141-152). Stanford, CA: The Walter H. Shorenstein Asia Pacific Research Center.

Moorthy, R., \& Benny, G. (2013). Does public Opinion Count? Knowledge and Support for An ASEAN Community in Indonesia, Malaysia, and Singapore. International Relations of the Asia-Pacific, 13(3), 399-423. . (2012). Is an "ASEAN Community" Achievable? Asian Survey, 52(6), 10431066.

Nesadurai, H. (2011). The ASEAN People's Forum (APF) as Authentic Social Forum: Regional Civil Society Networking for An Alternative Regionalism. Oxford: Routledge.

Pratidina, I. S. (2017). The Online Discourse of ASEAN Regionalism: A User and Content Analysis of Indonesian, English and Japanese Tweets. PhD dissertation, Hitotsubashi University.

Pratidina, I. S. (2018). The Political Opinion Leaders on Online Platform: Study Case on Japanese ASEAN Related Tweets. Jurnal Kajian Jepang, 2(1), 74-96.

Rathus, J. (2011). Japan, China and Networked Regionalism in East Asia. Palgrave Macmillan.

Rozman, G. (2012). East Asian Regionalism. In M. Beeson \& R. Stubbs (Eds.), Routledge Handbook of Asian Regionalism (pp. 22-32). Routledge.

Shin, G.-W. (2007). Regionalism and Nationalism in Northeast Asia. In G.-W. Shin \& D. C. Sneider (Eds.), Cross currents: Regionalism and nationalism in Northeast Asia (pp. 11-39). Stanford, CA: The Walter H. Shorenstein Asia Pacific Research Center.

Soesastro, H. (2006). Regional integration in East Asia: Achievements and Future Prospects. Asian Economic Policy Review, 1(2), 215-234.

Somantri, G. R. (2003). Towards Democracy Beyond Societies: A Study of Internet Practices in Indonesian Politics. In I. Banerjee (Ed.), Rhetoric and reality: The Internet challenge for democracy in Asia (pp. 97-121). Eastern Universities Press.

Statista. (2017). Statistics and Facts on Internet Usage in Japan. Retrieved February 3, 2017, from https://www.statista.com/topics/2361/internet-usage-in-japan/. 
Sukma, R., \& Soeya, Y. (2013). Reccomendations of the Study Group on ASEAN-Japan Stategic Partnership in ASEAN Community Building. In R. Sukma \& Y. Soeya (Eds.), Beyond 2015: ASEAN-Japan Strategic Partnership for Democracy, Peace, and Prosperity in Southeast Asia (pp. 15-23). Tokyo.

Terada, T. (2012). Becoming More Like a Normal Regionalism? Routledge Handbook of Asian Regionalism, 364.

. (2003). Constructing An "East Asian” Concept and Growing Regional Identity: From EAEC to ASEAN+ 3. The Pacific Review, 16(2), 251-277.

Thompson, E. C., \& Thianthai, C. (2008). Attitudes and Awareness Towards ASEAN: Findings of a Ten-Nation Survey. Singapore.

Yamamoto, T., \& Hernandez, C. (2003). Social and Cultural Dimensions in East Asian Community Building. In J. Wanandi (Ed.), ASEAN-Japan Cooperation: A Foundation for East Asian Community (pp. 171-183). Tokyo: Japan Center for International Exchange.

Yeo, L. H. (2006). Japan, ASEAN, and the Construction of An East Asian Community. Contemporary Southeast Asia: A Journal of International and Strategic Affairs, 28(2), 259-275. 